The poem does not appear in any of the works of Lytton and the library authorities give the author of the poem as $J$. L. McCreery and say "sometimes wrongfully attributed to Bulwer Lytton."

\title{
FIELD NOTES OF IOWA LAND SURVEYS AND THE RADIO
}

As a repository of valuable facts upon the actual establishment of permanent settlement in Iowa, we find the original notes of the surveyors who marked out our township and section lines of incomparable interest. It is not disputing or underrating the testimony of early residents upon the facts of first things in a locality, to go to the notes of those who established the permanent landmarks of that locality and there read what was recorded in confirmation or controversion of reminiscence.

It has been useful, then, to this department to refer to these notes when it is desired to know the exact location of earliest habitations, travelways and like evidences of the use of the land for our civilization.

The passing of the years since the establishment of our section corners has put out of life the direct recollection of probably every person who as a deputy surveyor certified his notes, and while we have encountered many names well known to us not only as such deputies, but as chainmen, axmen, mound-makers and other assistants who were required on a surveyor's staff and were required to autograph with him his reports, we have not been able thus far to learn within five years of one person living whose autograph was attached to these valuable data.

So it is fair to assume that the field notes of our land surveys are reliable in so far as they carry references to the evidences of both Indian and white life, Indian and white travelways, and the occurrence of fuel, building materials, soil quality, drainage and water supply that, under instructions of the surveyor general, the deputy surveyors were required to note.

A few curious variations from standard terms are employed that inspire a student to learn their cause. A surveyor in Audubon County noted on one line running north ten miles from his starting point a road, a trail and an Indian trail. In the usage of surveyors of adjacent townships the words slough, slue, and swale occur, while draw and ravine are employed to locate an 
identical though continuous water course of small account. The interchange of branch and run for like landmarks is frequent. So of road, trail, trace and their derivatives, wagon road, state road, Iowa City road, Mormon trace, bee trace, and Indian trace.

From the awakening of popular interest in early Iowa to which this department has contributed, and from the numerous calls for addresses on early Iowa themes, the Curator joined in "History Week," April 18-23, 1928, through the medium of the radio. The Bankers Life broadcasting station WHO, Des Moines, invited a continuation weekly of the series with the result that on each Monday from 4:30 to 5:00 P. M. statements have been made, explaining in turn each of the special phases of the work of our institution, with a characterization of the head of the respective divisions. Thercafter beginning on Monday, August 20, began half hours with the field notes of the section lines of each of our counties, beginning with Adair and continuing down the alphabet.

One can but be pleased with the appearance of interest in these dry themes. Letters and verbal expressions come in in scores bearing valuable suggestions, and not a few valuable objects such as photographs, maps and references to persons that strengthen: and enlarge the collections of the department and so benefit the present and future student of early Iowa

If one were concerned only with these field notes in reciting Iowa history by counties according to roll call, he could never: weary from sameness that at first might seem to rule. Adair, on the Mississippi-Missouri divide, crossed by two pre-settlement. travelways; Adams, adjacent, remote from both land and water; access, hence late in survey and settlement; Allamakee, of earlierthan-survey settlement, incredible physical impediments to the surveyor, but of immeasurahle interest to aboriginal and white: man, is bordered on the north by the Iowa-Minnesota boundary, itself a fine problem; Appanoose, on the southern border with; the Missouri state line to treat of in the surveys; Audubon, the first in the alphabet where our First Correction Line must be considered; each county has its special value.

And so on down there is revealed the interest to the broadcaster, and apparently to the listener, in these field notes now generally eighty years old, a variety resembling that in the Iowa records in the rocks, the plants, the institutions and the people. 
Copyright of Annals of Iowa is the property of State of Iowa, by \& through the State Historical Society of Iowa and its content may not be copied or emailed to multiple sites or posted to a listserv without the copyright holder's express written permission. However, users may print, download, or email articles for individual use. 